\title{
Paul Ricoeur and Religion
}

\author{
[ PAUl Ricouer E A Religião ]
}

\begin{abstract}
Resumo: Abstract: The path that Ricoeur peruses is twofold and not only by methodological precaution, that of philosophy, but also of the other philosophy, which is confused with non-philosophy, as is presented today by literature or science. Non-philosophy in Ricoeur is located in favor of religion and here lies linguistics, literary history, general hermeneutics and other disciplines. In this sense, philosophy is not simply critical, it is also placed in the order of conviction, and religious conviction itself has an internal critical dimension.
\end{abstract}

KeYwords: Metaphor; hermeneutics; anthropology; religion
Gerardo Miguel Nieves Loja * Universidad Nacional de Chimborazo, Equador
Abstract: O caminho pelo qual Ricoeur trilha é duplo e supera os limites de uma pura precaução metodológica, a pretensão filosófica, mas também trilha outro além da filosofia, o qual é confundido com a não-filosofia, como é considerado atualmente pela literatura ou pela ciência. A não-filosofia, para Ricoeur, caracteriza-se como suporte em favor da religião, e aqui podemos incluir a linguística, a história literária, a hermenêutica em geral e diversas disciplinas. Nesse sentido, a filosofia não se constitui apenas de crítica, mas também é entendida como ordem de convicção, e a própria convicção religiosa é portadora de uma dimensão crítica interna.

KEYwORDS: Metáfora; hermenêutica; antropologia; religião

\section{INTRODUCTION}

$\mathrm{T}$ his article presents the reflection of Paul Ricoeur's work on religion, which is extensive and pluridisciplinar. The French thinker published in different historical times and in different publishing houses. Most of his works are in French. In any case, the theme of religion in Ricoeur must be sought in his different reflections, because he never published an article or book that speaks exclusively on this subject. For this reason, it was necessary to revise his numerous publications.

We start off with a brief biographical description and the main sources of inspiration of his writings. Then we talk about the man capable of doing good and not only as a subject of guilt. This articule also deales with issues such as evil against God, power, phenomenology and hermaneuticacs that precisely help to better understand the theme of religion and, more specifically, the problem of evil, revelation, testimony and

* Doctor (PhD) en Filosofía por la Universidad de Estrasburgo, Francia. Actualmente es docente investigador de la Universidad Nacional de Chimborazo, Ecuador, en la Facultad de Ciencias PolíticasyAdministrativas.m@ilto: gnieves@unach.edu.ec/gnievesloja@yahoo.es 
conviction and about parables, one of Ricoeur's favorite subjects. However, it is not easy to approach the subject of religion according to Ricoeur, this is precisely because of the extreme care that he had in dealing with issues of philosophy and religion. Futhermore, the permanent effort is not to force interpretations that could damage the credibility of both disciplines of knowledge.

One of the most eminent philosophers of France at the end of the 20th century is Paul Ricoeur. He was born in Valence in 1913. He had a difficult childhood given the premature death of his parentes, thereby was educated by his grandparents. In the time of Hitler, he was made a prisoner of war. It is recounted that during his childhood in Rennes, he did not have much relation with Catholicism of the time in front of the Protestant minority. However, with the passage of time, he acquired a great recognition in spaces of Christian Catholic confession. He became a professor at French universities of Strasbourg, the Sorbonne and Nanterre. He also taught at the University of Louvain in Belgium, and at the American University of Chicago. Ricoeur a confessed protestant died in the year 2005. His opponents included traditionalists bourgeois and the leftist bourgeois but not the socially committed Catholics.

In the beginnings Ricoeur was interested in thinkers like Bergson, Diderot, Voltaire, Rousseau, Jacques Maritain, Gabriel Marcel - for whom he had great admiration. Other personalities that he admired were, the historian of religions Mircea Eliade and the philosopher Gadamer. Later he develoded inclinacion filosofical teories like the German existentialism by Karl Jaspers and the phenomenology of Edmund Husserl from which he translated the book Ideen I. The latter being a remarkable contribution to make known these thoughts in France. In addition, he studied the symbolic discourse and took charge of renewing considerably the hermeneutics, that is the science of the interpretation of the texts. He also attached value to the conflicts of interpretation by making dialogues between hermeneutics and linguistics, psychoanalysis, phenomenology and biblical exegesis. Ricoeur, faced with obstacles, had the habit of confrontacion rather that beating about the bush like a coward. His boldness kept him in the field of philosophy, in which he committed himself to, treating particular problems rather than than just answer questions like, what is philosophy? Ricoeur had the merit of not mixing philosophy and theology (Ricoeur, 2011: 140).

To read Ricoeur is an invitation to reopen the subject of religion: to understand what can be an equitable analysis of beliefs, that is to be led to admit that a religious tradition is not a monotonous set of statements. He regarded himself as a novice (amateur) in regard to the interpretation of the biblical texts, without entering into matters of faith and love, but of hope. Once the intellectus spei has been recovered, and not only the intellectus fidei, the spirit of religion can in this way contribute to the questioning of philosophy and the discourse does not close, a debate is initiated (Vincent, 2008: 22). From childhood Ricoeur learnt to read the Bible not in a literal sense but, rather, advancing a pneumatological conception that inspires and conducts daily life. In particular the Psalms, the writings of Wisdom and the Beatitudes, occupied a very important place more than dogmas. His spiritual life consisted of private Bible prayer reading and the examination of conscience, always supported in the axis of the Bible. Critical axis was a duality that finally marked all his life (Ricoeur, 2011: 16).

Ricoeur, never disguised his adherence to the Reformed Protestant faith. This was a minority grupo in comparison to the great catholic majority that was predominate in his area. The path that he took is two-way not only by methodological precaution, that of philosophy, but also of the other philosophy, which is confused with nonphilosophy, as presented today by literature or science. Non-philosophy in Ricoeur is located in favor of religion, here lies linguistics, literary history, general hermeneutics and other disciplines (Ricoeur, 2008: 26). In this sense, philosophy is not simply critical, it is also placed in the order of conviction, and religious conviction itself has an internal critical dimension. 


\section{THE POWER OF GOD? INABILITY OF MAN?}

According to Ricoeur, christianity in particular has imposed a pessimistic view of the human condition, thus justifying philosophical criticism in the name of reason and emancipation (Feuerbach, Nietzsche, Marx). However, the question that arises is whether the unity between religion and misery is constitutive or not. Ricoeur asserts that an assiduous reading of religious traditions leads to the conclusion that such unity can not be considered so fatal, and that the image of the mankind who looms is not ambiguous. Therefore, religion plays a role in defense of the human condition, against the accusation that only philosophy and other disciplines can do.

It used to be said that religions had a responsibility in imposing a negative view of the human condition, the self-deprecation of human capacities that go hand in hand with the magnificence of God's power or gods, as Feuerbach and Nietzsche held. It is precisely against this backdrop and analyzes that Ricoeur takes the defense of the "able man" (l'homme capable) through a path of return, of deconstruction of the evidences of thinkers with marked scientific rigor. And it is precisely in his book Soi-même comme un autre, where he answers and explains what the is able man: it is the answer to the question of I can speak, I can do, I can tell and imputable. In any case, it is the question: who can speak, who can do, who can be counted, who can be counted on his own actions, and thus Ricoeur takes possession of the notion of "narrative identity" in two expressions: mêmeté (durability in time) e Ipséité (principal of change ane novelty) the so-called hermeneutics of self (Ricoeur, 1990: 167).

Ricoeur's effort consists in giving the guilty man access to the "able man". Hence, the idea "I can speak" is located in the active and suffering subjects of the epic, tragedy and Aristotelian theory of action, where the subjects are interlocutors. For example, Homeric characters and tragic heroes do not stop talking about their actions. They are named when they make themselves known, the philosopher makes them speak of their actions. The ego is not a lexical term of the system of a language, but a selfreferential expression by which it designates itself as something irreplaceable. In addition, this self-designation of the speaking subject is located in a context of interlocution composed of the otherness: the spoken word is addressed to the other. A subject capable of saying: "I, so and so, my name is Paul Ricoeur" (Ricoeur, 1990: 146). The establishment of "able man" means that he o she is able to speak, act, be responsible morally, legally and politically.

The "I can" is the ability to bring events in the physical and social environment of the acting subject, it is the statement: I did it. These were the declarations of the Homeric characters and the tragic heroes, they were able to affirm it by pointing to a cause, rather than an intention, it is a beginning in itself. Consequently, the power to do consists in a power to begin. It's an initiative in which the power to act is made, what one feels capable of doing (Ricoeur, 2004: 150).

Personal identity is projected as narrative identity in that "I can count and be counted". I this sense, Ricoeur has a very close proximity to the scheme of Aristotle's Poetics in the fact of "put into intrigue" (muthos) with a representation (mimésis) of the action, composed of intentions, causes and chances, of concordances and discordances. The character, himself narrates intrigues full of imagination, so that the reader recognizes himself in the character and is seduced by the narrative (ipséité). At the same time, the character learns to count differently, appropriates and appears the ability to promise (ipse). However, in the confrontation with the other, narrative identity reveals his fragility (Ricoeur, 2004: 150).

Regarding the imputable, Ricoeur starts from the question about who is capable of imputation, and also other questions arise: who speaks? Who does what? Who counts? These questions are set out to clarify the responsibility, which is logically framed within a culture. Culure is the author of moral and legal doctrine where 
responsibility is framed by elaborate codes, placing crimes and penalties in the scenery of the balance of justice. In a strictly legal sense, imputation refers to the written law, which has the obligation in civil law to repair the damage caused and in criminal law that of subjecting to the penalty. Consequently, the obligation to repair the damages and to inflict pain. However, according to Ricoeur what matters is the legal analysis of the metaphor, to hold and attribute an action to someone as the true author of a reprehensible action. The culprit receives a penalty that has a criterion to make him suffer (faire souffrir) because of his mistake o omission. But the issue of imputation on the side of actual or potential victims of violent action remains. In addition, referring to Hans Jonas, he also alludes to the fact of shared responsibility and the future at the moral level (2004: 163).

\subsection{Phenomenology AND hermeneutics}

According to Ricoeur, there is no methodological difference between hermeneutics and epistemology, these are two intelligibility projects: two perspectives that intersect in abundance. In the first place, because the term hermeneutics comprises three aspects: first, it's a precise method with rigorous rules. This is the case of the philology and the exegesis of great classic texts as of the jurisprudence. Secondly, a reflection on what is the nature of understanding, its conditions and its functioning. Lastly, a more ambitious axis, a type of philosophy that is presented as another way of intelligibility and which seeks to understand scientific processes. As it can be seen, this process is very similar to that Gadamer, in the sense that there is an evaluation of the interpretive tradition of hermeneutics, the passage from epistemology to ontology. In any case, hermeneutics constitutes in epistemology where the notion of meaning saturates intelligibility (Ricoeur, 2011: 114). Hermeneutics is not only the relationship between the sage and the text, but also the relation with the collective interpretations, these are the readings which animate the text. A medieval thinker said that the text grows with its readers (Ricoeur, 1999: 21).

However, the work of Ricoeur in its genesis and transformation of his thought, is a philosophical project. Before being hermeneutic, it is a phenomenological and anthropological project, which leads to discover the limits of the method in the distinction of the involuntary and evil, facing the challenge represented by the enigma of evil. Here, religion is imposed as a new object of study that is not qualified as religious but as mythical and poetic. It is undeniable that Ricoeur has the merit of articulating the different, of solving the contradictions between philosophical criticism and philosophical hermeneutics. He makes his study based on solidly argued documents. He does not discuss any interpretation but, what he does, is to interrogate himself before the accusations and looks for a discussion (Ricoeur, 1961:300).

Ricoeur, in his phenomenology, scrupulously assumes the methodological precept of collecting the evidence, interrogates himself, judges, returns to the sources, and embarks on a path of deconstruction of the evidences with a thorough examination of the works, carrying out, in that way, free and productive research. It is important to emphasize that from his works in matters of the theory of religion, was carried out during the numerous debates that were carried out on subjects mainly cultural. For example, L'interpretation, Essai sur Freud, and also L'ideologie et l'utopie. There were also meetings and debates on Spinoza, Freud, Marx, Nietzsche, Rawls, Arendt, Weber, Höffe, Bouretz, Garapon, Taylor, Kierkegaard, Marcel and many others, with those whom Ricoeur established theoretical arguments and dialogues (Vincent, 2008: 31).

\subsection{RELIGION AND INTERPRETATION}


It should be remembered that Ricoeur attributes responsibility to religions for having imposed a negative view of the human condition and the self depreciation of human capacities that go in parallel and in opposition with the power of God, or of the gods. He points out that in Feuerbach, religion as a reflection of the human essence and God as the creation of man and in Nietzsche, religion es the origin of fear. However, far from attributing these thinkers as deniers only of the divine condition, it is necessary to emphasize in them the defense of the human being, because they consider man as an entrepreneurial being and able to succeed in what he has chosen. In this sense, Ricoeur also assumes the defense of the human condition without denying the divinity (Ricoeur, 1967: 43).

Ricoeur had the argumentative ability to resist lies and violence that any religion could encourage. Hence all reading, including religious, must be interpreted as an exercise of freedom in front of the sacred text. Unfortunately, the great defenders of power know this and that is why they refuse to read texts critically. All reading, including religious, is an exploration of meanings, hence all read text must be reread. In addition, reading is an art to which interpretive techniques should serve and not vice verser. In this way, interpretation serves to underline what art is: it is for life and it is at the service of an understanding and of living in a different way. Reading then plays the role of mediation between the world of the living and the world of (sacred world) texts that witness unsuspected possibilities of living. In addition, reading has a function of shock and unity between the imaginary world of the text and the effective world of the reader. In this way, reading, interpretation, and the text itself count as the first concepts of a general hermeneutics. (Vincent, 2008: 36).

With regard to the Gospels, there are four ways of modulating the message and speaking of the power of salvation, but also of understanding the status of the message in question: that of interpretation and fulfillment of the older scriptures. In this regard, we can see that the relationship between general hermeneutics and biblical hermeneutics is complicated to the point that the hermeneutic is confronted with a critical issue. In the ecclesial context, faith is defined above all as an acceptance of the doctrine. In this context, the subject of the intelligence of faith disappears and grants triumph to the norms that are imposed: the matter of faith is then confused with that of the conformity of belief; with that of orthodoxy and its means of imposing. This regime of orthodoxy was frequently rejected by Ricoeur. His criticism is firm and frequently indirect. For this reason, he hopes that philosophy will help the believer to better understand meanings and words as they are: faith, belief, religion, tradition. The subject of reading, the right to read and interpreting are also intimately linked to the narrative of Adam. (Ricoeur, 2008: 40).

Ricoeur choose to read biblical literature in the company of the exegetes, but not that of the theologians to whom he looked with a certain suspicion. Nevertheless, one of the theologians who influenced him notably was the Protestant theologian, Karl Barth. The said theologian is author of the book Dogmatique, that was constituted in one of the main inspirers of the spirit of resistance against the Nazism of Hitler, and at the same time one of the major critics of the theology of Thomas Aquinas. Taking sides in his exegesis, Ricoeur engages in the study of literary treatises and the semantics of biblical narratives, thus takes distance from Bultmann's work, due to the philosophical heritage of Heidegger's Dasein which he considers to be for death, while Ricoeur claims to be until death. In addition, Heidegger in his quest to return to classical Greek wisdom, treated the philosophical tradition as a uniform set of discourses, disqualifying ordinary language. He also devoted little importance to the problems related to culture and memory and attached too much importance to a future emptiness of being (Ricoeur, 1986: 97).

With regard to language, metaphors and concepts, Ricoeur relies on Aristotle, and frequently quotes the aphorism "being is said in multiple ways". In 1975 Ricoeur 
dedicated himself to the study of metaphor, linguistics and literary studies to renew the analysis of religious phenomena. In this sense, the concept of metaphor is twofold. On the one hand the decision to give priority to the study of religious language rather than to the aspect of religious experience. And on the other hand, in the book of Métaphore, instead of retaking the old opposition between truth and non-sense, the metaphor appears as the procedure by which the speaker reduces distance by changing the meaning of words. Talking about metaphor is a decision with the commitment to give meaning to the statement that seems to be missing. On the side of the listener or the reader, availability and interpretive generosity come to their encounter, their qualities depend largely on the existence of certain favorable cultural conditions (Vincent, 2008: 48).

The commitment to analysis by the hermeneut results in a critique of the systematic disqualification of which religion is the object. Ricoeur, for example, analyzes the prayer of Jesus to his father, Our Father. In his analisis, he emphasizes the fact that semantic or symbolic character is addressed to God as Father and especially as our Father, and is not therefore the Father of a single group of people or of one Church. Thus, the conception of the plural origin of believing folks (Ricoeur, 2004: 50). It is not, therefore, that one religion is more importante than the other. The ideal is that religious confessions can cohabit in the same public space and not that each region has its religion. This does not prevent the complete separation of church and state at the institutional level. In addition, the same policy has a religious dimension even though it does not have institutional inscription (Ricoeur, 2011: 103)

With regard to education, Ricoeur wonders why the students knew much better about the Greek, Roman, or Egyptian pantheon than the prophets of Israel or the parables of Jesus. They knew all the loves of Zeus, the adventures of Ulysses, but these students have never heard of Paul's letter to the Romans or the Psalms. One has to take into account that these texts have founded French culture, and it could even be say the same to Latin American countries. This is a difficult problem to solve, he reiterates. In any case, these young people have no access to their own past, to their cultural heritage, which contains the Greek heritage, as well as Jewish and Christian sources. The wars of religions are sometimes taught in history, but the context in which they are carried out, as well as the meaning of predestination in Luther's work, and the Eucharist in the Catholic Church is not clearly mentioned. This situation constitutes a true amputation of culture (Ricoeur, 2011: 197).

Finally, Ricoeur was not interested in institutional ecumenism, he rather believed in the pluralistic origin of Christianity. Nevertheless, he always recognized cordial relation with the Jesuits of the rue de Sèvres in Paris, as well as the great friendship he had at the Catholic Institue of Paris (Institut Catholique de Paris).

\section{EVIL AS CONTINGENCY}

In his book Finitud et culpabilité, Ricoeur, analyzes the symbol that allows to designate the point of insertion of the evil in the human reality in the form of a not being, possessing therefore it's proper existence. The ultimate test to which we are sent to is the enigma of free will that unites and is united. To analyze the problem of evil, he resorts to the myth of the fall, and affirms that evil in humanity is not explained by inheritance, nor by the fall of a perfect being in the beginning, but there is a tradition of evil, a interhuman connection in evil. The individual's sin is the materialization of the evil that was already in him by greed and without of him in his environmente. Evil is given, but Ricoeur does not agree to transfer it to an external instance out of the person: there is the good that lies deep in every person (Fèvre, 2003: 63). The symbolism of evil in Ricoeur, presents man as a being exposed to evil, and susceptible to evil, but not 
intrinsically evil; the man captivated in fault has his will oriented towards the good.

Narration makes us think, and question's us according to Ricoeur. For example, where does evil come from? Is not caused by God? Does God allow evil? To think is not to know but above all, to think about the Bible: it cannot be blind and read out of context. The meaning of the adamic narrative is not to be taken as an indisputable lesson and that makes us feel sinful; Ricoeur wonders if sin really is present in this narrative. The Adam and Eve story must be understood as literary characters in a narrative and not as historical personage, although it is true that it tells us of an extremely serious fall. Ricoeur considers evil as a contingent, historical structure; as a principle of fallibility (faillibilité), a weakness of a being exposed to the present evil, susceptible to do evil (Ricoeur, 1995: 28). Hence, he conceives evil as the capacity to make someone suffer in the historical present and, following Hannah Arendt, it can be said that only those who do not think are capable of doing evil, that is, infringe suffering on the other.

The biblical writings are plural. This plurality is accentuated by the symbolic imputation of each of the texts to a singular author. In any case, evil is linked to different types of narratives: tragic, orphic and biblical. In this work, Ricoeur payed close attention to Kant's interpretation, which emphasizes that according to the Adamic narrative, the imprisonment of freedom is represented as the result of a choice. In this sense, the christian faith is understood as an act of giving credence to (evangelical) narration. Futhermore, it must also be remembered that religious belief is ordinarily defined by various doctrinal contents such as creation, fall, alliances, incarnation or salvation, which have a more ethical than moral perspective. Hence, we must speak of the horizon of belief where no one can claim to be the proprietor of the truth. That is, one has to be on the horizon of a no fixed reality but communicates, hence the believer speaks of hope. In this context, Ricoeur considers religion as a worldview, and not as an instance that accuses the human being of his sin, as in the doctrine of Augustine of Hippo (Ricoeur, 1999: 22)

We can understand the logic of the overabundance of the first christian theologian, Paul of Tarsus, when he speaks of grace. Hope gives us a renewed broader understanding than of dialectial ethics and morality in the face of a over moralistic view of things. In this sense, the parable of the Good Samaritan speaks of the gift of charity: the Samaritan gives money to the caretaker in exchange of the good care. Ricoeur, in commenting on Paul, affirmed that the most secular institution, the legislature, the less ecclesiastical, if it is just, if it actas according to its function, if it cooperates with the growth of humanity, is one of the ways of man's salvation. The point is to know how to look for the superabundance of grace by which God replicates abundantly over evil. It is believed that sin abounds from without but that grace overflows within the human being. Grace humanizes and has enormous transforming power.

\section{REVELATION}

From the onset, it could be said that for Ricoeur, the term "revelation" has to be read kerigmatically, not a historical - critical reading, or even a canonical reading. It is not a call to obedience, but a call to reflection and to meditation - Andenken (Ricoeur, 1998: 314).

The issues of intertextuality, the theoretical question and the practical question, are central to Ricoeur's hermeneutics. He believes that we must redefine the concepts of faith and reason. His proposal is to rectify the concept of revelation. He deems it essential to distinguish very well in religious language, three levels of discourse: that of living faith (or that of charcoal), that of confession of faith, and that of doctrinal construction. Ricoeur considers that the first level should be privileged; here Ricoeur 
enters the debate not as a theologian but as a believer enlightened by the exegete, for whom the biblical texts do honor. Ricoeur insists that the truth, from the point of view of a well-understood faith, is the (eschatological) object of hope. In this regard, he says that the criticism of pure reason is not a feeling, or emotion, it is rather a process, an operation, that is, the act of putting a limit to the pretension of intelligence and the sensitivity to which intelligence is united. This act of hopelessness is already an act of hope (Ricoeur, 1990: 92).

One of Ricoeur's merit is that of formulating the literary genres represented and highlighting the main characteristics of each of them. He chooses to begin with, the prophetic discourse: it is a discourse pronounced in the name of and is not due to a superior importance of a given discourse over others. The reason for this choice is of a critical nature. It seeks to interrogate the content of discourse and the notion of revelation, generally understood from the model of the prophetic word in which the voice of the other appears and that of God himself through the prophet (Vincent, 2008: 93).

There is a second discursive genre mentioned by Ricoeur, that is narrative discourse. In the said genre the autor disappears. Ricoeur points out that not all the stories told in the Bible are the same in revelation. For example, Exodus and the liberation narratives form the central elements of the confession of faith of ancient Israel. But the hermeneuta does not forget to point out the complication of the narrative forms; in the Bible, this complication appears in particular in the unfolding narrative: an event (Ricoeur, 1969: 42).

According to the philosopher Austin that Ricoeur made known in in France, "to say" is to "do", then it can be said that the fact of narrating is much more than inventing or to repeat an intrigue: a space of symbolic belonging is drawn from anyone who assumes the narration. What Ricoeur says and expresses, is that he is in favor of a christianity that is capable of uniting convictions and responsibilities (Ricoeur 1995: 95).

Ricoeur is interested in the existence of other forms of biblical religious discourses, often considered minor. The prescriptive discourse revolves around the idea of the will of God, where the notion of the imperative is exaggeratedly accentuated to the point that, under the eyes of its adversaries, the affirmation of this will, or its privileged environment, the law of God becomes an arbitrary synonym of sanctity and an indisputable heteronomy. The hermeneut, then, shows three aspects: first, the destination to the memory of the narrative picture of the gift of the law; second, an alliance in which the horizon is universalist. The alliance is not just a normative framework, it is also a symbolic space of variations open to ethical feelings, from irreducible feelings to a single sense of duty. Thirdly, the Torah is not an invariant, it is historical. It lends itself to the eschatological imagination of a New Covenant.

Wisdom, as Ricoeur points out, is often despised, on the pretext that it is reduced to a lesson of resignation in the face of events. In this sense, he stresses the fact that suffering and unhappiness are not evidence of guilt.

The last genre is the hymn illustrated above all by the Psalms. Praise: the psalms of past deliverances, are transformed into invocations addressed to God present in the second person. The Psalms are a space of variations open to feeling and therefore the feeling of dependence. Frequently, the term of discourse corresponds to the specific framing of reality. God allows himself to be known through the tradition of discourses in which He appears in a position of reference. To this great faith, Ricoeur proposes a hermeneutic conception of the plurality very close to Hannah Arendt: the idea of revelation does not correspond to that of inspiration that occurs in the framework of the prophetic sort; the idea of revelation must go hand in hand with that "secret". 


\section{TeStimony AND CONVICTION}

The hermeneut has the task of being the conveyor of belief, capable of reflection and self-criticism to the point of radically revising the comprehension and extension of a central concept which is revelation. Ricoeur proceeds to a critical examination of the notion of conscience. In modern philosophy the noction of conscience is central and is impregnated with implications concerning matters of knowledge, religion and, more precisely, the religious language of some interest to the philosopher. There is a spirit of critical cooperation that dialogues. In this case, the first duty of the philosopher is to ask about the self-understanding of the subject as consciousness and, above all, about the claim of transparency and autonomy of consciousness.

A testimony is good because the witness reveals and awakens an unsuspected capacity of attention in the other. This is the capacity to which Descartes denominated generosity, and which Ricoeur ascribes to the presence of goodness in the depths of the human person, in front of which evil is not able to fully absorb. In addition, Ricoeur points out that a testimony has an ethical manifestation and that only the absolute is on the horizon, a situation that is beyond ethics and morality.

Belonging to a belief is not synonymous with blind belonging, but with a dynamic and critical faith. To have an attitude of self-donatation is fundamental or offer oneself forgetting oneself. This is the testimony given by the great historical archetypes: the suffering servant, the persecuted just. One can speak of Socrates or of Jesus, only to mention some names. This would be the radical difference between testimony and a caricatured form of presentation of the sacred, where losing would be no more than a tactic aimed at getting more. It would be forming predicates of the divine as we can disqualify the false witnesses; it is recognizing the true witnesses as we identify those who preach the divine; the event is our teacher (Ricoeur, 2004: 126).

In conclusion, the analysis of testimony allows us to understand that all dependence is not heteronomous. That is to say it is necessary to deconstruct paradigms that promote submissive wills. Therefor the need is a contest of conviction, where God is not only a point of escape, but a source of infinite possibilities.

\section{The PARABLES}

Ricoeur never got tired in putting the accent on the plural of the exclusive genres represented in the Biblical corpus. It is about showing that tradition is not opposed to innovation, but is dialectically linked to it. Futhermore, it's about showing that shape changes can ensure a lot of sense. In order to carry out this demonstration, the hermeneut joins the very particular narratives, of very modest appearance as are the parables, typical of the discourse of Jesus, although with some traces in the Old Testamen, and by which Ricoeur felt a late interest (Ricoeur, 2011: 130).

The parables are inscribed in a very wide network, where not only includes the discourses attributed to Jesus, sapiential statements and eschatological statements, but also the very acciones of Jesus. In this sense, miracles have the same meaning as parables; these are stories treated as fictions. Ricoeur strikes the similarity between parables and the life of Jesus, which leads him to underline this surprising innovation, legitimately undoubtedly very propitious to possible speculations.

Jesus proclaimed God in parables, but the early Church proclaimed Jesus as the parable of God. The parables stage the extravagance with a metaphorical religious language. Kant in his critique of false religion and of the false Church, manifests that religion is always in dispute with false religion. That is to say, the religion of statutes; a triumphant Church with the ambiguous image of a meditating Church, far from hope and destined only to close roads by means of sanctions and rewards, far from the divine 
paternity in which Jesus manifested with the expression My Father which consists of a unique relationship of mutual knowledge, of recognition. In Jesus, true fatherhood and true sonship are shown (Vincent, 2008: 138).

\section{Conclusion}

Ricoeur's philosophical position, in the conflict between reason and belief, was that of a committed arbitrator. However, his commitmente is to "disarm" adversaries and to remind them that they can find in their respective traditions dialogical resources that are often hidden. But Ricoeur knows that the exhortation is not enough, thus always advocated for a generous conception of secularism, as well as a broad cultural horizon of each one since translation is a difficult model to ignore.

With regard to the meaning of secularism, plurality is a demand for justice. However, the word secularity is very often wrong understood and therefor a source of misunderstanding. Ricoeur was a great defender of the public school. Since the secular cultural life of a people cannot only be by abstention, but also by the encounter of cultural and contrary currents. Therefore, secularity is related to life and not to death. It is in itself the modren conscience, the recognition of participation. It is a symbolic space constituted by a plurality of traditions that are open to one another.

Ricoeur, being a defender of the public space, considers that the teacher is the one who awakens, the one who provokes trust in the other, who believes that he is not the keeper of the truth. The thinker is the one who renounces his pride and the certainty of knowing. In this context, religious language, rather than "religion", must expand its discourse to the point of a better understanding of the other. Beleving therefore, is not a matter of merly repeating, but of assuming a work of critical distancing (generosity), so that the hermeneutics will awaken the sense of a dialogism and promote debates. All inter-religious confrontation must be avoided, since there is the risk of losing all singularity and all flavor.

\section{REFERENCES}

RICOEUR, P. (2011), La critique et la conviction, Paris: Pluriel

RICOEUR, P. (2009), Finitude et Culpabilité, Paris: Points

RICOEUR, P. (2004), Parcours de la reconnaisance, Paris: Stock

RICOEUR, P., (1999), Noms de Dieux, Bruxelles: Alice

RICOEUR, P. (1998), Penser la Bible, Paris: Seuil

RICOEUR, P. (1995), Réflexion faite, Paris: Esprit

RICOEUR, P. (1990), Soi-même comme un autre, Paris. Seuil

RICOEUR, P. (1986), Du texte à l'action, Paris: Seuil

RICOEUR, P. (1969), Le conflit des interprétations, Paris: Seuil.

RICOEUR, P. (1967 juil - sept 6), Philosophie et religión chez Karl Jaspers. Revue d'historie et de philosophie, Paris: Puf

RICOEUR, P. (1961), Civilisation universele et cultures nationales, Paris: Seuil

VINCENT, G., (2008), La religión chez Ricoeur, Paris: Éditions Ouvriers. 